\title{
2: $102066824-102103403$
}

National Cancer Institute

\section{Source}

National Cancer Institute. 2: 102066824-102103403. NCI Thesaurus. Code C45074.

Physical location of IL1R2_Gene 